\title{
Biology and control of the groundnut leafminer, Aproaerema modicella (Deventer) (Lepidoptera: Gelechiidae)
}

\author{
T. G. Shanower*, J. A. Wightman and A. P. Gutierrez' \\ Legumes Entomology, ICRISAT, Patancheru PO, Andhra Pradesh 502 324, India and ${ }^{\dagger}$ Division of \\ Biological Control, University of California, Berkeley, 1050 San Pablo Avenue, Albany, CA 94706, \\ USA
}

Abstract The groundnut leafminer, Aproacrema modicella (Deventer) (Iepidoptera: (ielechiidac), is an important pest of several legume crops in South and South-East Asia. For groundnut, yicld losses of $250 \%$ have been reported. It: addition to groundnut and soybean (the main crops attacked). 12 alternative host plants have been reported. A. modicella is present throughout the region, although it has been studied most intensively in India and Thailand. Research conducted over the past 10 years has provided a good understanding of the biology. life cycle and natural enemies of this pest. Research on management has focused on chemical control. This paper reviews the literature on the host plants, distribution, biology and control of $A$. modicella. emphasizing research reported since 1980 . Aspects of A. modicella coology that need further study are also indicated.

Keywords Groundnut; Arachis; Aproaerema modicella; groundnut leafminer; natural enemies; biology; host plants

\section{Taxonomy and distribution}

The groundnut leafminer (CiLM), Aproaerema modicella (Deventer) (I epidoptera: Gelechiidac), is a serious pest of groundnut and soybean in South and South-East Asia (Wightman et al., 1990). Amin (1983) has called it the most important groundnut pest in India. Originally described as Anacampsis nerteria Meyr. from specimens collected in India (Meyrick. 19(06), five other binomials have referred to the same pest: Biloba subsecivella Zcller, Stomopteryx nerteria Mcyr.. Stomopteryx nertaria Mcyr., Stomopteryx subsecivella Zeller, and Aproaerema nerteria Meyr. The uncertain taxonomy was due to the existence of two, non-congeneric leaf-miners: one from South Africa is now called Stomopteryx subsecivella (Zeller); the second is the Indian-Indonesian groundnut leatminer, Aproaerema modicella (Deventer) [J. D). Bradley, British Museum (Natural History) personal communication in Mohammad, 1981). Deventer (1904), in Mohammad, 1981) originally described $A$. modicella from a moth collected in Java, Indonesia.

The geographical range of $A$. modicella is restricted to South and South-Fast Asia, from Pakistan to (hina and as far south as the Philippines and Sri Lanka. It has been reported from Pakistan, India, Sri Lanka, Bangladesh, Myanmar, Thailand, Laos, Kampuchea,

"To whom correspondence should be addressed
Vietnam, China, the Philippines, Indonesia and Malaysia (Mohammad. 1981: Campbell, 1983; Islam et al. 1983; (rowe, 1985). In India, where GLM has been studied most extensively, it is found in Tamil Nadu, Andhra Pradesh, Karnataka, Maharashtra, Madhya Pradesh, Gujarat, Punjab, Delhi, Rajasthan, Orissa and West Bengal (Mohammad, 1981).

With the exception of Boreria hispida (Rubiaceae), (iLM feeds only on leguminous host plants (Table 1 ).

Table 1. Host plants of Aproaerema modicella

\begin{tabular}{|c|c|}
\hline Scicntific name & Reference \\
\hline Arachis hypogata 1 . & Maxwcll-Lefroy and Howlett. $19(19$ \\
\hline (ilvcint mal (l..) Merr. & Ramakrishna Ayyar, 1940 \\
\hline $\begin{array}{l}\text { Vigna radiata (l ..) Wilacek } \\
(=\text { Phaseolus atureus })\end{array}$ & Prasad et al. , 1971 \\
\hline Cajamus cajam (I .) Millsp. & Bainbridge-Fletcher, 1920 \\
\hline Medicago satia $\mathrm{L}$. & Sindhu, 1977 \\
\hline Psoralea corvlifolia L. & Maxwell-1 efroy and Howlett. I9(k) \\
\hline Inigofera hirsua $\mathrm{I}$ & Jai Rao and Thirumalachar, 1977 \\
\hline $\begin{array}{l}\text { Vigna umbellata (Thunb.) } \\
\text { (Ohwi and Ohashi }\end{array}$ & \\
\hline $1=$ Phaseolus calacaratus & Jai Rac and Thirumalachar. 1977 \\
\hline Glvcine soja Sicb. \& Zucc. & Vanhall, 1922 (in Mohammad, 1981) \\
\hline Trifolium alexundrium 1 .. & $\begin{array}{l}\text { Thontadarya, Jai Rao and Kumar, } \\
1979\end{array}$ \\
\hline \multicolumn{2}{|l|}{ Teramnus labiolis (I.) } \\
\hline Spreng & Dis and Misra, 1984 \\
\hline lablab purpureus $\mathrm{I}$. & Das and Misra. 1984 \\
\hline Rhynchosia minima DC. & Srinivasan and Siva Rao. 1984 \\
\hline Borreria hispida K. Sch. & Srinivasan and Siva Rao. 1984 \\
\hline
\end{tabular}

0261-2194/93/01/0003-08

(C) 1993 Butterworth-Heinemann Ltd 
Several are crop plants, the most important being groundnut (Arachis hypogaea L.), soybean [Glycine $\max$ (L.) Merr.], pigeonpea [Cajanus cajan (L.) Millsp.] and alfalfa (Medicago sativa L.). Phisitkul (1985) tricd unsuccessfully to rear GLM on a varicty of other plants, sunhemp (Crotalaria juncea L.), winged bean [Psophocarpus tetragonolobus (L.) D.C.], yard long bean [Vigna sinensis (L.) Saviex Hask subsp. sesquipedalis Fruwirth], siratro (Macroptilium atropurpureum L.), hamata (Stylosanthes hamata L.), cowpea [Vigna sinensis (L.) Savicx Hask], showy crotolaria (Crotalaria pallida Ait.), and sword bean (Canavalia gladiata D.C.). Females oviposited on these plants at a much lower rate than on groundnut and soybean, and larvae did not survive beyond the first instar.

\section{Life-cycle and population dynamics}

Maxwell-Lefroy and Howlett (1909) and BainbridgeFletcher (1920) were among the first to describe and document the life cycle of GLM. Cherian and Basheer (1942), Kapadia, Bharodia and Vora (1982) and Phisitkul (1985) also give detailed accounts of GLM biology. Small $(<1.0 \mathrm{~mm})$ oval eggs are laid on the undersides of groundnut leaflets, stems and petioles. Fecundity averages between 86.6 and $185.8 \mathrm{cggs}$ per female, although in one study a single female produced 473 eggs (Cherian and Basheer, 1942; Gujrati, Kapoor and Gangrade, 1973). Egg production has been shown to be temperature dependent with significantly lower production at 15 and $35^{\circ} \mathrm{C}$ than at $30^{\circ} \mathrm{C}$ (Shanower, 1989). The surface of the egg is covered with longitudinal pits which reminded one author of the pits on groundnut pods (reference in Bainbridge-Fletcher, 1920). Sixty degree-days above $12.4^{\circ} \mathrm{C}$ are required for GLM egg development (Shanower, 1989). Under ficld conditions, eggs generally hatch in $3-4$ days but may require 6-8 days at lower temperatures (Kapadia et al., 1982).

First-instar larvac typically chew through the epidermis to reach the leaf mesophyll upon hatching. Early instars create short serpentine mines, which widen into blotches as the larvae grow. Later instars leave the mine and web together two or more leaflets. Final-instar larvae are approximately $6.0 \mathrm{~mm}$ long and very active. Males and females can be distinguished in the larval stage by the distinctive pink gonads of the male which are visible through the cuticle. Larval development requires approximately 325 degree-days above a threshold temperature of $11.3^{\circ} \mathrm{C}$ (Shanower, 1989). Under field conditions at ambient temperature, larval development lasts between nine and 28 days (Cherian and Basheer, 1942; Sandhu, 1978; Kapadia et al., 1982).

Different numbers of instars have been reported in the literature. Kapadia et al. (1982) reported three, Gujrati et al. (1973) four, Amin (1987) five, and Islam et al. (1983) six larval instars. Head capsule measure- ments indicate that, in peninsular India, GLM larvac pass through five instars (Shanower, 1989).

Pupation occurs within the webbed leaflets and requires 72 degree-days above a threshold of $14.7^{\circ} \mathrm{C}$ (Shanower, 1989) and can be completed in 3-10 days at ambient temperatures (Cherian and Basheer, 1942; Sandhu, 1978). The egg-to-adult life cycle is completed in roughly 450 degree-days (Shanower, 1989) or 15-28 days in southern India (Cherian and Basheer, 1942). In northern India, when mean temperatures range between 14 and $22^{\circ} \mathrm{C}$, the life cycle may require $37-45$ days (Sandhu, 1978).

\section{Seasonal population dynamics}

A. modicella has been an important pest of groundnut in India for $>20$ years (Amin and Mohammad, 1980). Continuous cultivation of groundnut using irrigation, or a groundnut/soybean rotation, allow GLM populations to build up (Wightman and Amin, 1988). Even in the absence of groundnut or soybean, GLM populations can persist on one of scveral wild hosts (Table $I$ ). More than 3000 GLM larvae have been found on a single Psoralea corylifolia L. shrub, indicating the potential of this plant as an alternate host (Manoharan and Chandramohan, 1986). Alternatively, GLM may survive the extremely hot, dry Indian summer in pupal diapause or aestivation (Jagtap, Bothe and Deokar, 1985).

Leafminer populations peak in July and August in Thailand (Campbell, 1983), although other authors also report high population densities in November and December (Mohammad, 1981). In Bangladesh and India the densest populations of GLM occur at the end of the postrainy season, March and April (Amin and Mohammad, 1980); Islam et al., 1983). In India, GLM is often a problem towards the end of the rainy season (September and October), especially in drought or lowrainfall years (Amin, 1983). GLM populations fluctuate widely between seasons. At ICRISAT, in peninsular India, GLM population densities have been recorded regularly since 1980, in unsprayed groundnut (cv. Kadiri 3) trials with three or four observations per season and up to 100 plants per sample (unpublished data). Population densities ranged from one to $>320$ larvae per plant. Extremely high densities ( $>50$ larvae per plant) were recorded in two rainy seasons (1984 and 1987 ) and two postrainy scasons (1981 and 1982). In the other seasons, densities ranged between 10 and 20 larvae per plant.

Two GLM generations per crop are typical in Thailand (Campbell, 1983), whereas in China seven generations have been reported on a single soybean crop (Yang and Liu, 1966). Three to four generations per season are common on groundnut in India, although five generations have been reported during the rainy season in south India (Logiswaran and Mohanasundaram, 1986) 


\section{Climatic factors}

Abiotic factors, principally rainfall, humidity and temperature, are frequently suggested as causes of population fluctuations. Khan and Raodeo (1987) observed GLM populations over two years in Tamil Nadu. High populations were recorded from August through February, but in March declined to a low level. The authors claimed that high rainfall was the key factor regulating GLM populations, although their data do not support this conclusion. The high populations observed in August-September occurred during a high rainfall period; populations declined in March when no rain was recorded (Khan and Raodeo, 1987).

Amin (1987) has suggested that heavy rainfall reduces leafminer populations, although Wheatley et al. (1989) found that water from an overhead irrigation system did not lower (il M density. Lewin et al. (1979) found a significant negative correlation between GLM incidence and rainfall: higher GLM incidence was correlated with lower rainfall. Temperature, within the range experienced in the trial, was also positively correlated with GLM incidence and accounted for more of the variation than rainfall (Lewin et al., 1979). Another study at the same location revealed a significant negative correlation between infestation and temperature (Logiswaran et al., 1982). Experiments using a rain simulator indicated that the physical impact of rainfall on GLM eggs and larvae does not significantly increase mortality (Shanower, 1989). However, rainfall may have a more subtle influence (e.g. increasing humidity and favouring fungal pathogens) on GLM population dynamics.

\section{Damage and yield loss}

The groundnut leafminer reduces groundnut and soybean yields by feeding on leaves, thereby reducing the photosynthetically active leaf area. Islam et al. (1983) reported that the feeding activity of a single larva will destroy $34.8 \mathrm{~cm}^{2}$ of leaf tissue. This is equivalent to consuming $6-10$ groundnut leaflets, depending on the genotype, and seems excessive for such a small caterpillar. Shanower (1989) measured the consumption of individual larvae and calculated that on average $179.3 \mathrm{~mm}^{2}$ of leaf arca was eaten.

Jagtap, Ghulc and Deokar (1984) found that insect pests, principally GLM and Aphis craccivora Koch, accounted for a $16 \%$ reduction in pod dry weight in variety JL 24 over a 3-year period (equivalent to $3(1) 3 \mathrm{~kg}$ $\left.h^{-1}\right)$. Logiswaran and Mohanasundaram (1985) reported pod yield losses of $>50 \%$ in Tamil Nadu. Yield increases of up to $65 \%$ have been obtained in sprayed plots compared with unsprayed (check) plots (Sivasubramanian and Palaniswamy, 1983; Rajput, Dalaya and Awate, 1985). However, using this technique it is difficult to separate the losses attributable to GLM from those caused by other insects.

Tej Kumar and Devaraj Urs (1983) used screen cages and artificially infested groundnut plants with different levels of GLM. A regression of yield loss versus infestation revealed that each $1 \%$ infestation of (ILM resulted in $1.2 \%$ yield loss. Data from screen cages can be mislcading because the cages reduce sunlight, thus possibly confounding the results.

The impact of GLM on groundnut growth and yield is in part determined by the time of infestation. An infestation of five larvae per plant 10 days after emergence has a much greater impact than 20 larvac per plant at 75 days after emergence. Ghule et al. (1987b) found that groundnuts need protection from GLM between 45 and 75 days after emergence; however, this is true only if GLM populations are low, early in the season. A recommended action threshold in India is 61 70) larvac per 100 leaflets (Chewande, Nandagopal and Reddy, 1987).

\section{Cultural control and host-plant resistance}

Several cultural methods have been recommended for control of GLM, although only intercropping and manipulation of planting date have been tested. Logiswaran and Mohanasundaram (1985) found lower GLM larval densities when groundnut was intercropped with sorghum, millet or cowpea, than in monoculture groundnut at $30 \times 10 \mathrm{~cm}$ spacing. However, the lowest (iLM larval densities in this trial were recorded in monoculture groundnut at close spacing $(15 \times 10 \mathrm{~cm})$. Mulching with rice straw had no effect on (il M levels but did have a positive effect on parasitism levels: monocropped groundnut at $30 \times 10 \mathrm{~cm}$ spacing had the lowest level of parasitism whereas a similar monocrop at $15 \times 10 \mathrm{~cm}$ spacing had the highest; intercrop treatments all had intermediate levels of parasitization (Logiswaran and Mohanasundaram, 1985). The authors did not discuss the differences between treatments nor did they suggest the mechanism involved.

The effect of sowing date on (BLM infestations has been the focus of two studies: the first study (Lewin et al., 1979) showed that early sowing led to higher infestations of (BLM, whereas the second study (Logiswaran et al., 1982) concluded that later plantings were more heavily attacked.

Progress has been made in developing GLM-resistant or -tolerant cultivars. GLM resistance has been demonstrated in a wide range of genotypes, including spreading, Spanish bunch, and Valencia growth habits (ICRISAT, 1986). One variety, ICGV 86031, has shown good tolerance to GLM as well as to other defoliators (ICRISAT, 1991). ICGV 86031 is an improved genotype that may be grown in GLM. endemic areas and may be used as a suitable parent for germplasm enhancement by national agricultural research centres (ICRISAT, 1991).

Bunch varieties are generally considered to be less susceptible to GLM, although Motka, Bhalani and Bharodia (1985) have shown enhanced growth and development of GLM on these types. Growth rate, 
body weight and percentage survival of larvae and pupae, and weight and longevity of adults were compared in 10 varicties: larval, pupal and adult weights were significantly higher on the bunch variety JL 24 than on other varicties. Larval survival rate was also higher and adults lived significantly longer when reared on this varicty (Motka et al., 1985).

(jI.M-resistant soybcan varietics have not, as yet, been found. Mundhe (1980) compared 20 varieties and found no differences in GLM populations until 75 days after sowing. In another trial 18 varieties were compared (Shetgar and Thombre, 1984), but again no differences in leafminer populations were observed. More recently, 40 soybean varicties were evaluated during two rainy seasons and all were attacked by (il.M, although threc varicties had significantly lower larval populations (Shrivastava, Srivastava and Deole, 1988).

\section{Natural control}

Natural control, by discases, predators and parasitoids, is important in suppressing (iI.M population growth. At least three discase agents (nematodes, viruses and fungi) infect (iLM larvac in India. Unidentified mermithid nematodes have been found infecting larvac (Kothai, 1974 in Mohammad, 1981: Srinivasan and Siva Rao, 1986), as was a new nuclear polyhedrosis virus (Godse and Patil, 1981). The fungus Aspergillus flavus has also been recovered from GLM larvac (Oblisami, Ramamoorthi and Rangaswami, 1969). In some generations up to $30 \%$ of the larvac are killed by viral and fungal pathogens (Shanower et al. 1993).

Several predators have been identified that attack GLM larvac but their impact has not been quantified. Maxwell-Lefroy and Howlett (1909) reported that Odynerus punctum Fabr. (Hymenoptera: Eumenidae) would attack GLM larvae and carry them away. The larvae of a carabid (Chlaenius sp.) have been observed attacking (iLM larvac in the field (Shanower and Ranga Rao, 199(0). Predation by spiders and robber flies (Diptera: Asilidae) has also been reported (Srinivasan and Siva Rao, 1986).

The most important and abundant GLM natural enemies are parasitic Hymenoptera (Table 2). The parasitoid community associated with GLM is large and complex, involving at least two trophic levels. Table 2 includes both primary and secondary parasitoids reared from GLM. Shanower et al. (1993) found nine primary

Table 2. Parasitoids reared from Aproaerema modicella

\begin{tabular}{|c|c|c|}
\hline Pamily Parasitoid & Host plant & $\begin{array}{l}\text { Stage } \\
\text { attacked }\end{array}$ \\
\hline \multicolumn{3}{|l|}{ Bethylidac } \\
\hline Goniozus sp. & $\begin{array}{l}\text { Groundnut and } \\
\text { soybcan }\end{array}$ & Larva \\
\hline $\begin{array}{l}\text { G. stomopterycis Ram \& Subba } \\
\text { Rao }\end{array}$ & Groundnut & larva \\
\hline Perisierola sp. & Groundnut & larva \\
\hline
\end{tabular}

\begin{tabular}{|c|c|c|}
\hline Family Parasitoid & Host plant & $\begin{array}{l}\text { Stage } \\
\text { attacked }\end{array}$ \\
\hline \multicolumn{3}{|l|}{ Braconidac: } \\
\hline Apanteles sp. & $\begin{array}{l}\text { Ciroundnut and } \\
\text { soybean }\end{array}$ & Larva \\
\hline A. javensis Rohwer & (iroundnut & Larva \\
\hline A. singaporensis Szcp. & Groundnut & Larva \\
\hline A. litae Nixon & Soybcan & larva \\
\hline Avga choaspes Nixon & Groundnut & Larva \\
\hline A. nixoni Subba Rao \& Sharma & Groundnut & l.arvat \\
\hline Bracon sp. & Groundnut & Larva \\
\hline B. brevicornis Wesm. & Groundnut & Larva \\
\hline B. gelechiac $\Lambda$ shm. & $\begin{array}{l}\text { Groundnut and } \\
\text { soybean }\end{array}$ & I arva \\
\hline B. (Microbracon) hetetor Say & Groundnut & Larva \\
\hline (helonus (Microchelonus) sp. & $\begin{array}{l}\text { (iroundnut and } \\
\text { soybean }\end{array}$ & Larva \\
\hline C. blackburni Cam. & Groundnut & Larva \\
\hline C. curvimaculatus Cam. & Ciroundnut & Larva \\
\hline Phancrotomasp. & Groundnut & larva \\
\hline \multicolumn{3}{|l|}{ Coraphronidac: } \\
\hline Aphanagmus fijiensis (Ferriere) & Groundnut & Larva \\
\hline Ceruphron sp. & Ciroundnut & Larva \\
\hline \multicolumn{3}{|l|}{ (halcididac } \\
\hline Brachymeria sp. & Groundnut & $\begin{array}{c}\text { Larva and } \\
\text { pupa }\end{array}$ \\
\hline B. plutellophaga (iir. & Giroundnut & $\begin{array}{c}\text { Larva and } \\
\text { pupa }\end{array}$ \\
\hline B. mimuta (I..) & Groundnut & larva \\
\hline B. wittei Schmitz & Groundnut & Larva \\
\hline Eucepsis (sp.) & Groundnut & Larva \\
\hline \multicolumn{3}{|l|}{ Flasmidac } \\
\hline Elasmus anticles Walker & Groundnut & larvat \\
\hline F. brevicornis (iahatn & Soybcan & Larva \\
\hline E. sp. nr. luteus Crawford & Groundnut & Larva \\
\hline \multicolumn{3}{|l|}{ Fincyrtidac } \\
\hline Capidosoma sp. & Groundnut & larva \\
\hline \multicolumn{3}{|l|}{ Fulophidac } \\
\hline \multicolumn{3}{|l|}{ Eurvscotolynx coimhatorensis } \\
\hline Rohw. & Groundnut & larva \\
\hline Oomyzus sp. & Groundnut & Larva \\
\hline P'diobrius sp. & (iroundnut & Larva \\
\hline $\begin{array}{l}\text { Stenomesiovideus ashméadi } \\
\text { Subba Rao \& Sharmat }\end{array}$ & $\begin{array}{l}\text { Groundnut and } \\
\text { soybcian }\end{array}$ & larva \\
\hline Stenomesius sp. & Groundnut & I arva \\
\hline S. japonicus (Ashmead) & Groundnut & Larva \\
\hline Sympiesis (Asympiesiella) sp. & Groundnut & Larva \\
\hline S dolichogester Ashmead & Giroundnut & Larva \\
\hline S. india Gir. & (iroundnut & Larva \\
\hline Tetrastichus sp. & Giroundnut & Larvat \\
\hline \multicolumn{3}{|l|}{ Eupclmidac } \\
\hline Fupelmos sp. & Groundnut & $\begin{array}{c}\text { I arva and } \\
\text { pupa }\end{array}$ \\
\hline I. sp.nr. anpingensis & Groundnut & $\begin{array}{c}\text { I arva and } \\
\text { pupa }\end{array}$ \\
\hline \multicolumn{3}{|l|}{ Eurytomidac } \\
\hline Eurytoma sp. & Groundnut & L arva \\
\hline Plutarchia giraulti Subba Rao & Groundnut & Larva \\
\hline \multicolumn{3}{|l|}{ Ichneumonidac } \\
\hline Temelucha sp. & Giroundnut & Larva \\
\hline \multicolumn{3}{|l|}{ Pteromalidac } \\
\hline Dibrachys sp. & Groundnut & Larva \\
\hline Habrocytus sp. & Ciroundnut & larva \\
\hline Pteromalus sp. & Groundnut & Larva \\
\hline \multicolumn{3}{|l|}{ Trichogrammatidac } \\
\hline Trichogramma sp. & Groundnut & Egg \\
\hline
\end{tabular}

"Sources: Krishnamurthi and Usman. 1954: Subba Rao al al. 1965. Subba Ral and Sharma, 1966; Phisitkul, 1985: Srinivasaln and Siva Rao. 1986. Muthiah, 1991; Shanower et al., 1993 
body weight and percentage survival of larvae and pupae, and weight and longevity of adults were compared in 10 varictics: larval, pupal and adult weights were significantly higher on the bunch variety Jl. 24 than on other varieties. Larval survival rate was also higher and adults lived significantly longer when reared on this varicty (Motka et al., 1985).

GLM-resistant soybean varietics have not, as yet, been found. Mundhe (1980) compared 20 varieties and found no differences in GLM populations until 75 days after sowing. In another trial 18 varieties were compared (Shetgar and Thombre, 1984), but again no differences in leafminer populations were observed. More recently, 40) soybean varictics were evaluated during (wo rainy seasons and all were attacked by (iLM, although three varieties had significantly lower larval populations (Shrivastava, Srivastava and Deole, 1988)

\section{Natural control}

Natural control, by discases, predators and parasitoids, is important in suppressing (BLM population growth. At least three disease agents (nematodes, viruses and fungi) infect GLM larvate in India. Unidentified mermithid nematodes have been found infecting larvac (Kothai, 1974 in Mohammad, 1981: Srinivasan and Siva Rao, 1986), as was a new nuclear polyhedrosis virus (Godse and Patil, 1981). The fungus Aspergillus flaves has also been recovered from GLM larvae (Oblisami, Ramamoorthi and Rangaswami, 1969). In some generations up to $30 \%$ of the larvac are killed by viral and fungal pathogens (Shanower et al., 1993).

Several predators have been identified that attack GLM larvae but their impact has not been quantified. Maxwell-Lefroy and Howlett (1909) reported that Odynerus punctum Fabr. (Hymenoptera: Fumenidac) would attack (BLM larvae and carry them away. The larvac of a carabid (Chlaenius sp.) have been observed attacking (BLM larvac in the field (Shanower and Ranga Rao, 1990). Predation by spiders and robber flies (Diptera: Asilidae) has also been reported (Srinivasan and Siva Rao, 1986).

The most important and abundant GLM natural enemies are parasitic Hymenoptera (Table 2). The parasitoid community associated with GLM is large and complex, involving at least two trophic levels. Table 2 includes both primary and secondary parasitoids reared from GLM. Shanower et al. (1993) found nine primary

Table 2. Parasitoids reared from Aproaerema modicella ${ }^{A}$

\begin{tabular}{|c|c|c|}
\hline Family Parasitoid & Host plant & $\begin{array}{l}\text { Stage } \\
\text { attacked }\end{array}$ \\
\hline \multicolumn{3}{|l|}{ Bethylidae } \\
\hline Goniozus sp. & $\begin{array}{l}\text { Groundnut and } \\
\text { soybean }\end{array}$ & Larva \\
\hline $\begin{array}{l}\text { G. stomopterycis Ram \& Subba } \\
\text { Rao }\end{array}$ & Groundnut & I arva \\
\hline Perisierolasp. & Groundnut & l arva \\
\hline
\end{tabular}

\begin{tabular}{|c|c|c|}
\hline Family Parasitoid & Host plant & $\begin{array}{l}\text { Stage } \\
\text { attacked }\end{array}$ \\
\hline \multicolumn{3}{|l|}{ Braconidac } \\
\hline Apanteles sp. & $\begin{array}{l}\text { Groundnut and } \\
\text { soybean }\end{array}$ & Larva \\
\hline A. javensis Rohwer & (iroundnut & Larva \\
\hline A. singaporensis Szep. & Groundinut & Larva \\
\hline A. litae Nixon & Soybean & larva \\
\hline Avga choaspes Nixon & Groundnut & Larva \\
\hline A. nixoni Subba Rao \& Sharma & Groundnut & Larva \\
\hline Braconsp. & Ciroundnut & larva \\
\hline B. hrevicornis Wesm. & Groundnut & Larva \\
\hline B. gelechiae Ashm. & $\begin{array}{l}\text { Croundnut and } \\
\text { soybean }\end{array}$ & I arva \\
\hline B. (Microbracon) hebetor Say & Groundnut & Larva \\
\hline (helonus (Microchelonus) sp. & $\begin{array}{l}\text { Groundnut and } \\
\text { soybean }\end{array}$ & larva \\
\hline C. blackburni Cam. & Groundnut & larva \\
\hline C curvimaculatus Cam. & Groundnut & Larva \\
\hline Phanerotoma sp. & Groundnut & Larva \\
\hline \multicolumn{3}{|l|}{ Ceraphronidac: } \\
\hline Aphanagmus fijiensis (Ferriere) & Groundnut & Larva \\
\hline Ceraphron sp. & Groundnut & l.arva \\
\hline \multicolumn{3}{|l|}{ ('halcididace } \\
\hline Brachymeria sp. & Ciroundnut & $\begin{array}{c}\text { Larva and } \\
\text { pupa }\end{array}$ \\
\hline B. plutellophaga (iir. & (iroundnut & $\begin{array}{c}\text { I arva anc } \\
\text { pupa }\end{array}$ \\
\hline B. minuta $(1 \ldots)$ & (ircundnut & I.arva \\
\hline B. nitte Schmitz & Ciroundnut & Larva \\
\hline Eucepsis (sp.) & Groundriut & Larva \\
\hline \multicolumn{3}{|l|}{ Flasmidac } \\
\hline Elasmus anticles Walker & Groundnut & Larva \\
\hline Fibrevicornis (iahan & Soybcan & Larva \\
\hline E. sp. nr. luteus Crawford & Groundnut & I arva \\
\hline \multicolumn{3}{|l|}{ Fincyrtidae } \\
\hline Capidosoma sp. & Groundnut & Larva \\
\hline \multicolumn{3}{|l|}{ Fulophidac } \\
\hline \multicolumn{3}{|l|}{ Eurvscotolynx coimhatorensis } \\
\hline Rohw & Groundnut & larva \\
\hline Oomyzus sp. & Groundnut & Larva \\
\hline Pediobius sp. & Giroundnut & Larval \\
\hline $\begin{array}{l}\text { Stenomesionideus ashmeadi } \\
\text { Subba Rao \& Sharma }\end{array}$ & $\begin{array}{l}\text { Groundnut and } \\
\text { soybean }\end{array}$ & L.arva \\
\hline Stenomesius sp. & Groundnut & Larva \\
\hline S. japonicus (Ashmead) & Groundnut & Larva \\
\hline Sympiesis (Asympiesiella) sp. & Groundnut & Larva \\
\hline S. dolichogaster Ashmead & Ciroundnut & larva \\
\hline S india (iir. & Circundnut & Larva \\
\hline Tetrastichus sp. & (iroundnut & I arva \\
\hline \multicolumn{3}{|l|}{ Iupclmidac } \\
\hline Fupelmus sp. & Groundnut & $\begin{array}{c}\text { Larvat anc } \\
\text { pupa }\end{array}$ \\
\hline$\therefore$ sp.nr. anpingensis & (iroundnut & $\begin{array}{c}\text { Larva anc } \\
\text { pupa }\end{array}$ \\
\hline \multicolumn{3}{|l|}{ Eurỵtomidac } \\
\hline Furytoma sp. & Groundnut & l arva \\
\hline Plutarchia giraulti Subba Rao & Groundnut & larvi \\
\hline \multicolumn{3}{|l|}{ Ichneumonidac } \\
\hline Temelucha sp. & Groundnut & Larva \\
\hline \multicolumn{3}{|l|}{ Pteromalidac } \\
\hline Dibrachys sp. & Groundnut & Larva \\
\hline Habrocytus sp. & Ciroundnut & Larva \\
\hline Pteromalus sp. & Groundnut & Larva \\
\hline \multicolumn{3}{|l|}{ Trichogrammatidac } \\
\hline Trichogramma sp. & Groundnut & Egg \\
\hline
\end{tabular}

"Sources: Krishnamurthi and Usman. 1954; Subba Rao el al., 1965: Subba Rato and Sharma. 1966: Phisitkul, 1985: Srinivasan and Siva Rao, 1986. Muthiah, 1991: Shanower el al., 1943 
Govemment Consultation of Striga Control, Maroua, Cameroon (Rome: FAO), pp. 51-53.

OBILANA, A. T. and RAMAIAH, K. V., 1992. Striga (witchweeds) in sorghum and knowledge and future research needs. In W. A. J. Milliano, R. A. Fredericksen and G. D. Bengston (eds) Sorghum Millet and Diseases: a Second World Review (Patancheru, India: International Crops Research Institute for the Semi-Arid Tropics), pp. 187-201.

OGBORN, J., 1984. Research priorities in agronomy. In E. S. Ayensu, H. Doggett, R. D. Keynes, J. Marton-Lefevre, L. J. Musselman, C. Parker and A. Pickering (eds) Striga: Biology and Control (Paris: ICSU Press), pp. $195-212$

PARKINSON, V., 1985. Striga, serious threat to maize production in Africa and research being conducted at IITA. In Proceedings of OAU/FAO Workshop on Striga, Yaounde, Cameroon (Rome: FAO), pp. 47-57.

PIETERSE, A. H., 1985. Control of Striga at the level of the small-scale farmer. In Proceedings of OAU/FAO Workshop on Striga, Yaounde, Cameroon (Rome: FAO), pp. 23-27.

RAMAIAH, K. V., 1984. Patterns of Striga resistance in sorghum and millets with special emphasis on Africa. In E. S. Ayensu, H. Doggett, R. D. Keynes, J. Marton-Lefevre, L. J. Musseiman, C. Parker and A. Pickering (eds) Striga: Biology and Control (Paris: ICSU Press), pp. 71-92.
RAMAIAH, K. V., 1985. Hand-pulling of Striga hermonthica on pearl-millet. Tropical Pest Management, 31, 326-327.

RAMAIAH, K. V., 1991. Breeding for Striga resistance in sorghum and millet. In S. K. Kim (ed) Combating Striga in Africa (Ibadan, Nigeria: IITA), pp. $75-80$.

SANOGO, D., DEBRAH, S. K. and ADESINA, A. A., 1992. Crop production in sorghum-based cropping systems: A diagnostic study of four villages in the OHV and CMDT zones of Mali. ICRISATMASIP Economics sub-programme Progress Report No. 1, Bamako, Mali, 72 pp.

SAUERBORN, J., 1991. The economic importance of the phytoparasites Orobanche and Striga. In J. K. Ransom. L. J. Musselman, A. D. Worsham and $\mathrm{C}$. Parker (eds) Proceedings of the 5th International Symposium of Parasitic Weeds, Nairobi, Kenya, pp. 137-143.

SAUERBORN, J., MUSSA, H. and LINKE, K. H., 1991. Physical control of Striga. In S. K. Kim (ed) Combating Striga in Africa (Ibadan, Nigeria: IITA), pp. 55-60.

SMITH, J., 1992. Socio-economic characterization of environments and technologies in humid and sub-humid regions of West and Central Africa. Resource and Crop Management Research Monograph No. 10 (Ibadan, Nigeria: International Institute of Tropical Agriculture), $85 \mathrm{pp}$. 